DOI: $10.19195 / 0137-1134.115 .4$

\author{
JOANNA SUSŁO \\ ORCID: 0000-0003-0945-9291 \\ Uniwersytet Wrocławski
}

\title{
GRANICE UMOCOWANIA PROKURENTA SAMOISTNEGO
}

\begin{abstract}
Abstrakt: Artykuł traktuje o zakresie umocowania prokurenta samoistnego, ze szczególnym uwzględnieniem wątpliwości interpretacyjnych na tle obowiązujących przepisów. W pierwszej części opracowania dokonano egzemplifikacji czynności (poza)sądowych i innych, mieszczących się w granicach umocowania prokurenta, a następnie wyszczególniono katalog czynności, których dokonanie przez prokurenta wymaga udzielenia mu dodatkowego pełnomocnictwa. Poruszone zagadnienia prowadzą do rozważenia, czy prawodawca dostatecznie sformułował zakres umocowania prokurenta, a także czy zasadnie go ograniczył. W artykule formułowane są również postulaty de lege ferenda.
\end{abstract}

Słowa kluczowe: prokura, granice umocowania, czynności (poza)sądowe, prowadzenie przedsiębiorstwa, pełnomocnictwo szczególne, ograniczenia prokury

\section{WPROWADZENIE}

W świetle art. $109^{1} \S 1$ kodeksu cywilnego ${ }^{1}$ prokura jest pełnomocnictwem udzielanym przez przedsiębiorców — zarówno osoby fizyczne, osoby prawne, jak i jednostki niebędące osobami prawnymi, którym ustawa przyznaje zdolność prawną pod warunkiem jednak, że podlegają obowiązkowi wpisu do rejestru przedsiębiorców. Udzielić prokury mogą zatem przedsiębiorcy wymienieni w art. 36 ustawy o Krajowym Rejestrze Sądowym², a także osoby fizyczne prowadzące działalność gospodarczą na podstawie wniosku o wpis do Centralnej Ewidencji i Informacji o Działalności Gospodarczej (dalej: CEIDG), co potwierdza art. $109^{7}$ $\S 4$ k.c., który wyraźnie przewiduje, że śmierć przedsiębiorcy nie powoduje wygaśnięcia prokury ${ }^{3}$. W literaturze prezentowane jest również odmienne stanowisko, kwestionujące możliwość udzielania prokury przez osoby fizyczne, jako że ustawodawca obejmuje zakresem podmiotowym tylko tych przedsiębiorców, którzy

1 Ustawa z 23 kwietnia 1964 roku - Kodeks cywilny, Dz.U. z 1964 r. Nr 16, poz. 93 ze zm., dalej: k.c.

2 Ustawa z dnia 20 sierpnia 1997 roku o Krajowym Rejestrze Sądowym, Dz.U. z 1997 r. Nr 121, poz. 769 ze zm., dalej: k.r.s.

3 A. Kidyba, [w:] Prawo handlowe, red. A. Kidyba, Warszawa 2012, s. 149.

Przegląd Prawa i Administracji 115, 2018

(C) for this edition by CNS 
podlegają wpisowi do rejestru, natomiast CEIDG jest ewidencją ${ }^{4}$, a nie rejestrem. De lege ferenda należałoby ten przepis zmodyfikować poprzez doprecyzowanie, że chodzi o podmioty podlegające obowiązkowemu wpisowi do rejestru przedsiębiorców oraz CEIDG.

Prokura jest instytucją prawną należącą wyłącznie do obrotu profesjonalnego, ponieważ posłużyć się nią może tylko przedsiębiorca ${ }^{5}$. Prokurent jako pełnomocnik składa własne oświadczenie woli, ale działa w imieniu i z bezpośrednim skutkiem prawnym dla mocodawcy, co oznacza, że jego czynności wywołują skutki prawne bezpośrednio po stronie reprezentowanego ${ }^{6}$.

Szeroki zakres uprawnień przysługujący prokurentowi gwarantuje ustawa na podstawie art. $109^{1} \S 2$ k.c. prokury nie można ograniczyć ze skutkiem wobec osób trzecich, chyba że przepis szczególny stanowi inaczej. Takie zastrzeżenie uzasadnione jest postulatem pewności obrotu gospodarczego, a w tym - dążeniem do pogłębiania zaufania podmiotów trzecich do działań podejmowanych przez prokurenta. Nie oznacza to jednak, że zakres umocowania prokurenta jest nieograniczony. Ustawodawca, mimo że nie pozwala samemu mocodawcy na jego ograniczenie, sam dokonuje w nim wyłączeń ${ }^{7}$ (zob. art. $109^{3}$ k.c.). Treść art. $109^{1}$ $\S 2$ k.c. wskazuje jednocześnie, że zakres umocowania prokurenta ma charakter przepisu bezwzględnie obowiązującego (ius cogens). O ile zatem zakres tego umocowania wyznacza ustawa, o tyle źródłem umocowania jest oświadczenie woli przedsiębiorcy.

\section{CZYNNOŚCI SĄDOWE I POZASĄDOWE}

Na podstawie art. $109^{1} \S 1$ k.c. prokura obejmuje ex lege umocowanie do podejmowania przez prokurenta czynności sądowych i pozasądowych związanych z prowadzeniem przedsiębiorstwa. Ze względu na tak szerokie sformułowanie zakresu umocowania prokurenta nie sposób wyliczyć wszystkich czynności mieszczących się w ramach jego umocowania. W celu przybliżenia granic umocowania prokurenta samoistnego należy przyjąć, że czynności sądowe koncentrują się na reprezentowaniu przez prokurenta prowadzonego przez mocodawcę przedsiębiorstwa przed wszystkimi sądami, w tym Sądem Najwyższym, jak również przed organami państwowymi i samorządowymi. Przyjmuje się również, że prokurent bez oddzielnego upoważnienia może zawierać umowy o arbitraż (zapis na sąd polubowny), umowy z arbitrami (receptum arbitrii) i wszelkie inne porozumienia

4 Zob. M. Pazdan, [w:] Kodeks cywilny, t. 1. Komentarz do art. 1-44910, red. K. Pietrzykowski, Warszawa 2015, s. 444.

5 K. Osajda, [w:] Kodeks cywilny. Komentarz, t. 1, red. K. Osajda, Warszawa 2013, s. 839 n.

6 Wyrok WSA w Warszawie z 4 czerwca 2009 roku, VII Sa/Wa 486/09, Legalis nr 241252.

7 L. Moskwa, P. Moskwa, [w:] Kodeks cywilny, t. 1. Komentarz do art. 1-44911, red. M. Gutowski, Warszawa 2016, s. 712. 
w postępowaniu polubownym (na przykład odnośnie do miejsca arbitrażu lub języka postępowania), umowę o mediację lub o ekspertyzę, umowy prorogacyjne lub derogacyjne w zakresie jurysdykcji krajowej ${ }^{8}$. SN zwrócił w tym zakresie uwagę na rozróżnienie umocowania prokurenta od pełnomocnictwa procesowego, podnosząc, że ustawowe upoważnienie do dokonywania czynności sądowych związanych z prowadzeniem przedsiębiorstwa oznacza co prawda, że sam prokurent może być pełnomocnikiem procesowym, ale zarazem ustawowe umocowanie prokurenta do czynności sądowych nie tworzy eo ipso pełnomocnictwa procesowego, ponieważ do jego istnienia konieczne jest zawiśnięcie przed sądem konkretnej sprawy ${ }^{9}$. Jednocześnie w tezie komentowanego orzeczenia SN przyjął, że prokurent może udzielić pełnomocnictwa procesowego - także dalszego - osobom wymienionym w art. $87 \S 2$ kodeksu postępowania cywilnego ${ }^{10}$. O ile zatem prokurent nie ma możliwości ustanowienia prokury substytucyjnej ani przeniesienia wszystkich swoich uprawnień wynikających z przepisów prawa materialnego na inną osobę (zob. art. $109^{6}$ k.c.), o tyle nie istnieją ograniczenia w udzieleniu przez niego pełnomocnictwa procesowego. Jeśli natomiast prokurent zamierza sam działać w postępowaniu cywilnym, to jego kompetencje są niezwykle szerokie - może on bowiem wszczynać postępowanie (wnosić pozwy, wnioski), prowadzić je (na przykład zgłaszać wnioski w jego trakcie, wnosić środki odwoławcze, odbierać koszty), dokonywać czynności materialno-dyspozytywnych (na przykład zawierać ugody, składać oświadczenie o zrzeczeniu się roszczenia, uznawać roszczenia), a także podejmować czynności w postępowaniu zabezpieczającym i egzekucyjnym ${ }^{11}$.

Oprócz czynności sądowych na podstawie art. $109^{1} \S 1$ k.c. w zakresie umocowania prokurenta mieszczą się również czynności pozasądowe. Należy uznać, że chodzi tutaj o wszelkie czynności o charakterze materialnoprawnym, obejmujące przede wszystkim czynności prawne, na przykład podpisywanie czeków, udzielanie i zaciąganie kredytów i pożyczek, zawieranie umów o pracę, umów najmu i umów dzierżawy (przy uwzględnieniu art. $109^{3}$ k.c.) i o świadczenie usług, a także przejmowanie i poręczanie długów ${ }^{12}$. Pochylając się nad orzecznictwem sądów powszechnych, warto uzupełnić ten przykładowy katalog czynności pozasądowych o takie czynności prokurenta, jak: podpisanie weksli13 ${ }^{13}$, oświadczeń

${ }^{8}$ K. Pietrzykowski, [w:] Kodeks cywilny. Komentarz, t. 1, red. K. Pietrzykowski, Warszawa 2013, s. 383.

9 Uchwała SN z 24 lipca 2013 roku, III CZP 45/13, Legalis nr 703852.

10 Ustawa z 17 listopada 1964 roku — Kodeks postępowania cywilnego, Dz.U. z 1964 r. $\mathrm{Nr}$ 43, poz. 296 ze zm., dalej: k.p.c.

11 M. Gutowski, Komentarz do art. $109^{1}$ k.c., [w:] Kodeks cywilny. Komentarz 2016, red. M. Gutowski, Legalis.

12 J. Strzebińczyk, [w:] Kodeks cywilny. Komentarz, red. E. Gniewek, P. Machnikowski, Warszawa 2016, s. 262.

13 Orzeczenie SN z 10 maja 1935 roku, C II 354/35, Legalis nr 10816. 
o poręczeniu ${ }^{14}$, a także innych dokumentów prywatnych w imieniu mocodawcy ${ }^{15}$. Nadto, należy opowiedzieć się za dopuszczalnością dokonywania przez prokurenta innych czynności, takich jak przejawy woli podobne do oświadczeń woli, na przykład wezwania (dłużnika do spełnienia świadczenia) oraz zawiadomienia (o wadach rzeczy ${ }^{16}$. Orzecznictwo wskazuje także czynności o charakterze ściśle faktycznym, na przykład zlecenie przez prokurenta kontroli jakości pracy pracownika zatrudnionego w spółce $\mathrm{z}$ ograniczoną odpowiedzialnością, jak również wykonywanie przez prokurenta czynności, które charakteryzują osobę zarządzającą zakładem pracy w imieniu pracodawcy ${ }^{17} \mathrm{w}$ rozumieniu art. $241^{26} \S 2$ kodeksu Pracy ${ }^{18}$ w związku z art. $31 \S 1$ k.p.

Z przedstawionych przykładów wynika, że ustawowe umocowanie prokurenta obejmuje czynności procesowe, prawne oraz faktyczne. Nie ulega przy tym wątpliwości, że zarówno w zakresie czynności sądowych, jak i pozasądowych prokurent jest umocowany do przyjmowania pism i oświadczeń skierowanych do przedsiębiorcy ${ }^{19}$. Znamienne jest również to, że dla prawa do działania prokurenta nie jest istotne, czy dana czynność jest czynnością zwykłego zarządu, czy czynnością przekraczającą zakres zwykłego zarządu. Jest to jedna z cech, która odróżnia umocowanie prokurenta od umocowania pełnomocnictwa ogólnego z art. 98 k.c., które obejmuje jedynie czynności zwykłego zarządu.

\section{CZYNNOŚCI ZWIĄZANE Z PROWADZENIEM PRZEDSIĘBIORSTWA}

Przy ustalaniu granic umocowania prokurenta $\mathrm{w}$ ramach podejmowanych przez niego czynności sądowych i pozasądowych należy zwrócić uwagę na ostatni fragment treści art. $109^{1} \S 1$ k.c., zgodnie z którym prokura obejmuje umocowanie tylko do tych czynności, które „są związane z prowadzeniem przedsiębiorstwa”. A contrario, prokurentowi nie przysługuje prawo do podejmowania w imieniu i na rzecz przedsiębiorcy czynności sądowych i pozasądowych, które wykraczałyby poza czynności związane z prowadzeniem przedsiębiorstwa. Co do zasady nawet bardzo ograniczony związek danej czynności z prowadzeniem przedsiębiorstwa upoważnia prokurenta do działania w imieniu reprezentowanego ${ }^{20}$. Chodzi jednak

14 Orzeczenie SA w Poznaniu z 28 kwietnia 1992 roku, I ACr 111/92, Legalis nr 877828.

15 Orzeczenie SA w Szczecinie z 31 lipca 2014 roku, III APa 4/14, Legalis nr 1231561.

16 I. Ignatowicz, A. Wolter. K. Stefaniuk, Prawo cywilne. Zarys części ogólnej, Warszawa 2015, s. 115.

17 Orzeczenie SA w Szczecinie z 31 lipca 2014 roku, III APa 4/14, Legalis nr 1231561.

18 Ustawa z 26 czerwca 1974 roku - Kodeks pracy, Dz.U. z 1974 r. Nr 24, poz. 141 ze zm., dalej: k.p.

19 A. Kidyba, [w:] Kodeks cywilny - część ogólna, t. 1, red. A. Kidyba, Warszawa 2012, s. 668.

20 M. Gutowski, Komentarz do art. $109^{1}$ k.c., [w:] Kodeks cywilny. Komentarz 2016, red. M. Gutowski, Legalis (dostęp: 10.01.2017).

Przegląd Prawa i Administracji 115, 2018

(C) for this edition by CNS 
tylko o czynności dokonywane w stosunkach zewnętrznych. Przeważa pogląd, że prokurent nie może podejmować czynności w zakresie stosunków wewnętrznych przedsiębiorcy czy jego ustroju ${ }^{21}$. Są to bowiem czynności należące do prowadzenia spraw, czyli zarządzania przedsiębiorstwem, a istota prokury wyraża się w umocowaniu prokurenta do składania (odbierania) oświadczeń woli w cudzym imieniu ze skutkiem na zewnątrz, czyli wobec osób trzecich. Prokura nie obejmuje zatem działań w sferze wewnętrznych relacji przedsiębiorcy, na przykład prokurent nie może zwoływać organów kolektywnych osób prawnych ${ }^{22}$.

$\mathrm{W}$ tym kierunku podążyły również sądy gospodarcze, przyjmując, że prokurent nie ma ustawowego upoważnienia do występowania w postępowaniu rejestrowym (zob. wyrok SO w Szczecinie z dnia 4 lipca 2014 roku $^{23}$ ), co niejako stoi w sprzeczności z zaprezentowanym na wstępie niniejszego artykułu zakresem czynności sądowych, w których mieści się działanie prokurenta w imieniu mocodawcy przed wszystkimi sądami. Oznacza to, że aby zakwalifikować określone czynności sądowe jako przysługujące prokurentowi z mocy ustawy, należy bliżej zbadać przedmiot konkretnego postępowania. Prokura nie upoważnia bowiem do dokonywania takich czynności, które dotyczą sfery organizacyjno-prawnej mocodawcy oraz wykonania przez mocodawcę jego uprawnień bądź obowiązków prawnych, niezależnych od kwestii prowadzenia przedsiębiorstwa (zalicza się do nich zgłaszanie wniosków o wpis do rejestru danych dotyczących przedsiębiorcy, na przykład w przedmiocie zmiany umowy, statutu, zmiany w składzie zarządu itp.). Nie można zatem utożsamiać prokury z pełnomocnictwem do zastępowania zarządu spółki we wszystkich płaszczyznach związanych z wykonywaniem funkcji organu spółki. Tym samym dla skuteczności czynności podejmowanych w postępowaniu rejestrowym za spółkę prokurent nie może powoływać się na upoważnienie ustawowe, lecz powinien legitymować się dodatkowym pełnomocnictwem procesowym, na przykład do występowania w konkretnej sprawie, lub pełnomocnictwem rodzajowym, uprawniającym do występowania w sprawach określonego rodzaju ${ }^{24}$. Na ograniczenie umocowania prokurenta do czynności podejmowanych w stosunkach zewnętrznych zwrócił także uwagę NSA w wyroku z dnia 27 października 2009 roku ${ }^{25}$, precyzując, że ograniczenie zakresu prokury przesłanką związku z prowadzeniem przedsiębiorstwa wymaga rozważenia przedmiotu postępowania administracyjnego z prowadzeniem przedsiębiorstwa. Oznacza to, że sprawy prowadzenia przedsiębiorstwa winny być rozgraniczone na przykład od spraw nałożenia sankcji z tytułu samowoli budowlanej na inny podmiot.

21 K. Osajda, op. cit., s. 839 n.

22 Z. Radwański, Prawo cywilne - część ogólna, Warszawa 2009, s. 332.

23 Wyrok SO w Szczecinie z 4 lipca 2014 roku, VIII Gz 111/14, Legalis nr 1034103.

24 Ibidem.

25 Wyrok NSA z 27 października 2009 roku, II OSK 1690/08, Legalis nr 207850. 
Nie powinno natomiast budzić wątpliwości, że do czynności niezwiązanych z prowadzeniem przedsiębiorstwa zalicza się czynności dotyczące prywatnych spraw przedsiębiorcy (w zakresie jego praw osobistych, stosunków prawnych z zakresu prawa rodzinnego), niezwiązane z prowadzeniem przedsiębiorstwa, wreszcie czynności mające na celu zakończenie prowadzenia przedsiębiorstwa ${ }^{26}$.

\section{DEFINICJA PROWADZENIA PRZEDSIĘBIORSTWA}

W literaturze istnieją rozbieżności odnośnie do interpretacji zwrotu ,prowadzenie przedsiębiorstwa", z którym związane są czynności podejmowane przez prokurenta na podstawie art. $109^{1} \S 1$ k.c. Ukształtowały się dwa stanowiska. Zgodnie z pierwszym przedsiębiorstwo $\mathrm{w}$ rozumieniu komentowanego przepisu powinno być postrzegane globalnie i abstrakcyjnie, to jest w oderwaniu od konkretnego przedsiębiorstwa ${ }^{27}$. W przeciwnym razie, w przypadku gdy jeden przedsiębiorca miałby kilka przedsiębiorstw, kontrahent przedsiębiorcy mógłby zostać łatwo wprowadzony w błąd co do zakresu umocowania prokurenta. Tym samym ze względu na bezpieczeństwo i transparentność obrotu prokura powinna obejmować całość czynności sądowych i pozasądowych związanych z działalnością gospodarczą prowadzoną przez tego konkretnego przedsiębiorcę i tym samym uprawniać prokurenta samoistnego do działania w imieniu i na rzecz mocodawcy w zakresie wszystkich należących do niego przedsiębiorstw. Na marginesie należy wskazać, że poza zakresem artykułu pozostaje prokura oddziałowa, która w sposób przejrzysty wyznacza granice umocowania prokurenta do zakresu spraw dotyczących poszczególnych oddziałów. Zwolennicy drugiego stanowiska podnoszą, że przedsiębiorstwo na gruncie komentowanego przepisu należy traktować indywidualnie. Dokonując porównania obecnego przepisu z jego poprzednikiem jeszcze pod rządami innej ustawy, tj. art. $109^{1}$ k.c. w relacji do art. $61 \S 1$ kodeksu handlowego ${ }^{28}$, ustawodawca zrezygnował ze sformułowania ,jakiekolwiek przedsiębiorstwo". Zgodnie z archiwalnym brzmieniem tego artykułu ,prokura upoważnia do wszystkich czynności sądowych i pozasądowych, jakie są związane z prowadzeniem jakiegokolwiek przedsiębiorstwa zarobkowego". Zestawiając obecną i dawną definicję prokury, podnosi się, że utracił aktualność pogląd wyrażony i broniony pod rządami kodeksu handlowego ${ }^{29}$, że prokurent jest umocowany również do czynności związanych z prowadzeniem jakiegokolwiek, a więc każdego (mogącego obiektywnie istnieć, a niekoniecznie należącego do spółki

26 A Kidyba, [w:] Kodeks cywilny..., s. 669.

27 J. Strzebińczyk, op. cit., s. 262.

28 Rozporządzenie Prezydenta Rzeczypospolitej z 27 czerwca 1934 roku - Kodeks handlowy, Dz.U. z 1934 r. Nr 57, poz. 502 ze zm., dalej: k.h.

29 K. Pietrzykowski, op. cit., s. 383. 
handlowej - mocodawcy) przedsiębiorstwa zarobkowego ${ }^{30}$. Skoro ustawodawca zrezygnował z terminu ,jakiekolwiek przedsiębiorstwo", to znaczy, że w tym przepisie chodzi wyłącznie o indywidualnie oznaczone przedsiębiorstwo.

Rozważając argumenty prezentowane w literaturze, należy podkreślić, że właściwsze wydaje się stanowisko pierwsze, niejako wynikające z samej istoty i funkcji prokury, która oprócz przedsiębiorcy ma służyć przede wszystkim bezpieczeństwu obrotu gospodarczego, czyli między innymi pogłębiać zaufanie podmiotów trzecich do czynności podejmowanych przez prokurenta $\mathrm{w}$ imieniu i na rzecz przedsiębiorcy podlegającemu obowiązkowi wpisu do rejestru przedsiębiorców. Gdyby przyjąć, że zakres prokury dotyczy konkretnego przedsiębiorstwa, to niejako pośrednio wraca obowiązek ustalania przez kontrahenta, czy prokurent dokonuje czynności z zakresu działalności konkretnego przedsiębiorcy. Co więcej, ryzyko wadliwego ustalenia poniesie sam kontrahent, ponieważ dokonana czynność nie wywoła skutków. Ponadto, niekiedy samo rozważenie, czy dana czynność mieści się w zakresie działalności konkretnego przedsiębiorcy, jest (w skrajnych przypadkach) bardzo ocenne ${ }^{31}$. Inną kwestią jest to, że gdyby intencją ustawodawcy było zawężenie zakresu umocowania prokurenta do czynności związanych z konkretnym przedsiębiorstwem, dałby temu wyraz, analogicznie jak uczynił to w odniesieniu do prokury oddziałowej w przepisie art. $109^{5}$ k.c. ${ }^{32}$ Podsumowując, należy przyjąć, że sformułowanie „prowadzenie przedsiębiorstwa” w świetle art. $109^{1} \S 1$ k.c. zostało użyte w znaczeniu funkcjonalnym, ponieważ nie odnosi się do indywidualnie oznaczonego przedsiębiorstwa, tylko do działalności gospodarczej prowadzonej przez mocodawcę prokurenta.

\section{USTAWOWE OGRANICZENIE UMOCOWANIA PROKURENTA}

Taksatywny katalog czynności prawnych pozostających poza ustawowymi granicami umocowania prokurenta formułuje art. $109^{3}$ k.c., który stanowi, że do zbycia przedsiębiorstwa, do dokonania czynności prawnej, na podstawie której następuje oddanie go do czasowego korzystania oraz do zbywania i obciążania nieruchomości wymagane jest pełnomocnictwo do poszczególnej czynności. Wyłączenie tych czynności spod ustawowego umocowania prokurenta wynika z charakteru tych czynności, które mają kluczowe znaczenie dla bytu i funkcjonowania przedsiębiorstwa, jako że ich dokonanie może nie tylko doprowadzić do istotnego ograniczenia działalności przedsiębiorstwa, ale nawet do jego zakończenia. W związku z tym poza zakresem umocowania prokurenta pozostają takie czynności, jak na przykład sprzedaż, zamiana, darowizna przedsiębiorstwa, oddanie

\footnotetext{
30 Ibidem.

31 K. Osajda, op. cit., s. 842 n.

32 A. Kidyba, [w:] Kodeks cywilny..., s. 668 n.
} 
go do czasowego korzystania oraz wniesienie przedsiębiorstwa tytułem aportu do spółki bądź tytułem wkładu do spółdzielni ${ }^{33}$. Aby zatem prokurent mógł skutecznie dokonać tych czynności, musi uzyskać od mocodawcy dodatkowe pełnomocnictwo szczególne, czyli do poszczególnej czynności.

Chociaż katalog z art. $109^{3}$ k.c. jest katalogiem zamkniętym, to wywołuje liczne spory interpretacyjne. Po pierwsze, ograniczenie prokury co do ,zbywania” przedsiębiorstwa i nieruchomości nie jest jasne, jako że nie precyzuje, czy zakaz dotyczy zbywania tylko całości nieruchomości (przedsiębiorstwa), czy również poszczególnych jej (jego) części. Dopuszczenie możliwości zbycia części nieruchomości (przedsiębiorstwa) jest o tyle niebezpieczne dla mocodawcy prokurenta, że bez jego wiedzy mogłoby z czasem dojść w istocie do zbycia całej nieruchomości (przedsiębiorstwa). W doktrynie wskazuje się także na problem polegający na tym, że zakaz zbywania nieruchomości przez prokurenta, którego ustanowiono dla przedsiębiorcy zajmującego się obrotem nieruchomościami, powoduje, że instytucja prokury nie jest szczególnie użyteczna, ponieważ prokurent nie może dokonywać typowych i podstawowych dla takiego przedsiębiorcy czynności ${ }^{34}$.

Kolejną kwestią jest rodzaj czynności prawnych podlegających ograniczeniu ze względu na konsekwencje prawne. Według M. Pazdana zakresem zastosowania art. $109^{3}$ k.c. należy objąć nie tylko czynności prawne rozporządzające lub czynności o podwójnym skutku zobowiązująco-rozporządzającym, lecz także czynności zobowiązujące, w tym umowy przedwstępne zobowiązujące między innymi do przeniesienia własności nieruchomości lub ustanowienia na niej ograniczonego prawa rzeczowego ${ }^{35}$. Z tym stanowiskiem nie zgadzają się L. Moskwa i P. Moskwa, wskazując, że pierwszeństwo należy dać wykładni literalnej tego przepisu, który wprost nie wyłącza spoza zakresu umocowania tego typu czynności zobowiązujących ${ }^{36}$. Osobiście uważam, że ograniczenia $\mathrm{z}$ art. $109^{3}$ k.c. nie powinny być interpretowane rozszerzająco, dlatego przychylam się ku temu drugiemu stanowisku. Jednocześnie za niedopuszczalne należy uznać rozszerzanie zakazu określonego $\mathrm{w}$ art. $109^{3}$ k.c. poprzez analogiczne stosowanie tego przepisu do innych praw, na przykład użytkowania wieczystego.

Po wtóre, wątpliwości może budzić zakres obciążania nieruchomości (przedsiębiorstw). W doktrynie przyjęło się, że prokurent potrzebuje pełnomocnictwa do poszczególnej czynności w przypadku ustanowienia na nieruchomości hipoteki, użytkowania, służebności czy też własnościowego spółdzielczego prawa do lokalu mieszkalnego ${ }^{37}$. Obciążenie nieruchomości może także polegać na ustanowieniu

33 U. Promińska, [w:] Kodeks cywilny, t. 1. Część ogólna, red. M. Pyziak-Szafnicka, P. Księżak, Warszawa 2014, s. 1138.

34 Ibidem.

35 M. Pazdan, op. cit., s. 451.

36 L. Moskwa, P. Moskwa, op. cit., s. 712.

37 P. Nazaruk, [w:] Kodeks cywilny. Komentarz, red. J. Ciszewski, Warszawa 2014, s. 235. 
służebności gruntowej lub przewłaszczenia na zabezpieczenie ${ }^{38}$. Co do zasady za obciążenie nieruchomości należy uznać inne czynności zobowiązujące, powodujące utratę przez mocodawcę władztwa nad nieruchomością, jak choćby umowa najmu czy dzierżawy ${ }^{39}$. Pytanie, czy w każdym przypadku. Przyjmując taką definicję obciążania nieruchomości, prokura wydaje się całkowicie nieużyteczna dla przedsiębiorcy działającego na rynku najmu mieszkań i lokali gospodarczych, gdzie obciążanie składników przedsiębiorstwa jest typową czynnością. Przepis ten może również rodzić problemy w praktyce, na przykład w sytuacji nagłej potrzeby podnajęcia przez prokurenta niewielkiej części dużego przedsiębiorstwa. W świetle orzecznictwa SN (zob. wyrok SN z dnia 8 października 2014 roku $^{40}$ ) umowa najmu i dzierżawy stanowi „obciążenie” nieruchomości, a na kanwie art. 17 ustawy o księgach wieczystych i hipotece ${ }^{41}$ ujawnienie w księdze wieczystej prawa najmu oraz prawa dzierżawy rozszerza ich skuteczność erga omnes. Można by zatem pokusić się o stwierdzenie, że zakaz ten obejmuje tylko prawa obligacyjne wpisane do księgi wieczystej. W doktrynie większość zdaje się jednak twierdzić, że zawarcie przez prokurenta umowy najmu i dzierżawy nieruchomości wymaga uzyskania od przedsiębiorcy pełnomocnictwa do poszczególnej czynności, ponieważ umowy te powodują utratę przez przedsiębiorcę faktycznego władztwa nad nieruchomością ${ }^{42}$. Nie mniejsze wątpliwości budzi objęcie zakresem komentowanego przepisu zastawienia przedsiębiorstwa ${ }^{43}$, które pozwalałoby zastawnikowi zaspokoić się z dochodu, jaki przynosi przedsiębiorstwo ${ }^{44}$.

\section{PODSUMOWANIE}

Reasumując, należy podkreślić, że prokura jako pełnomocnictwo szczególne, określane ze względu na swoje przeznaczenie pełnomocnictwem handlowym, bez wątpienia przyznaje umocowanemu szerszy zakres uprawnień aniżeli pełnomocnictwo ogólne. Zakres ten musi być jednak ujmowany w granicach wytyczanych przez ustawowy wymóg pozostawania czynności (sądowych i pozasądowych) w związku z prowadzeniem przedsiębiorstwa. Nadto, niektóre czynności, chociaż są związane z prowadzeniem przedsiębiorstwa, nie mogą być podejmowane przez prokurenta, ponieważ dotyczą jego stosunków wewnętrznych, to jest ustroju. Prokura nie może być zatem rozumiana jako pełnomocnictwo nieograniczone.

38 U. Promińska, op. cit., s. 1139.

39 J. Strzebińczyk, op. cit., s. 264.

40 Wyrok SN z 8 października 2004 roku, V CK 76/04, Legalis nr 68427.

41 Ustawa z 6 lipca 1982 roku o księgach wieczystych i hipotece, Dz.U. z 1982 r. Nr 19, poz. 147 ze zm.

42 K. Osajda, op. cit., s. 843.

43 L. Moskwa, P. Moskwa, op. cit., s. 712.

44 K. Osajda, op. cit., s. 842. 
Jednocześnie z dużą dozą ostrożności należy podchodzić do katalogu z art. $109^{3}$ k.c., który wyłącza wskazane tam czynności spod ustawowego umocowania prokurenta, jako że rozumienie samego zbywania i obciążania nieruchomości (przedsiębiorstwa) nie tylko wywołuje liczne spory interpretacyjne, lecz także nie odpowiada potrzebom obrotu gospodarczego.

Wśród postulatów de lege ferenda na pierwszy plan wysuwa się potrzeba doprecyzowania pojęcia prokury poprzez jasne wyznaczenie jej zakresu podmiotowego, o czym była mowa w części pierwszej niniejszego artykułu. Po drugie, należałoby zmodyfikować opis czynności, które wymagają pełnomocnictwa szczególnego. Proponowane jest zatem następujące brzmienie art. $109^{3}$ k.c.: „Do zbycia składnika przedsiębiorstwa, jego zastawienia, do dokonania czynności prawnej, na podstawie której następuje oddanie go do czasowego korzystania, oraz do zbywania i obciążania całości lub części nieruchomości jest wymagane pełnomocnictwo do poszczególnej czynności”.

Wreszcie, przy ustalaniu granic umocowania prokurenta ustawodawca powinien mieć na uwadze przedsiębiorców działających na rynku obrotu nieruchomościami. Pożądane byłoby wyposażenie tych przedsiębiorców w prawo do umocowania prokurenta do wielokrotnego dokonywania „szczególnych” czynności na podstawie jednego dokumentu pełnomocnictwa (na przykład obowiązkowo zawierającego limit kwotowy wszystkich podjętych przez prokurenta czynności w określonym przedziale czasowym).

\section{BIBLIOGRAFIA}

Ignatowicz I., Wolter, A. Stefaniuk K., Prawo cywilne. Zarys części ogólnej, Warszawa 2015.

Kidyba A., Prawo handlowe, Warszawa 2012.

Kodeks cywilny - część ogólna, red. A. Kidyba, Warszawa 2012.

Kodeks cywilny. Komentarz, t. 1, red. K. Pietrzykowski, Warszawa 2013.

Kodeks cywilny. Komentarz 2016, red. M Gutowski.

Moskwa, L. Moskwa P., [w:] Kodeks cywilny, t. 1. Komentarz do art. 1-44911, red. M. Gutowski, Warszawa 2016.

Nazaruk P., [w:] Kodeks cywilny. Komentarz, red. J. Ciszewski, Warszawa 2014.

Osajda K., [w:] Kodeks cywilny. Komentarz, t. 1, red. K. Osajda, Warszawa 2013.

Pazdan M., [w:] Kodeks cywilny, t. 1. Komentarz do art. 1-44910, red. K. Pietrzykowski, Warszawa 2015.

Promińska U., [w:] Kodeks cywilny, t. 1. Część ogólna, red. M. Pyziak-Szafnicka, P. Księżak, Warszawa 2014.

Radwański Z., Prawo cywilne - część ogólna, Warszawa 2009.

Strzebińczyk J., [w:] Kodeks cywilny. Komentarz, red. E. Gniewek, P. Machnikowski, Warszawa 2016. 


\section{AKTY PRAWNE}

Rozporządzenie Prezydenta Rzeczypospolitej z 27 czerwca 1934 roku — Kodeks handlowy, Dz.U. z 1934 r. Nr 57, poz. 502.

Ustawa z 23 kwietnia 1964 roku — Kodeks cywilny, Dz.U. z 1964 r. Nr 16, poz. 93.

Ustawa z 17 listopada 1964 roku — Kodeks postępowania cywilnego, Dz.U. z 1964 r. Nr 43, poz. 296. Ustawa z 26 czerwca 1974 roku — Kodeks pracy, Dz.U. z 1974 r. Nr 24, poz. 141.

Ustawa z 6 lipca 1982 roku o księgach wieczystych i hipotece, Dz.U. z 1982 r. Nr 19, poz. 147.

Ustawa z 20 sierpnia 1997 roku o Krajowym Rejestrze Sądowym, Dz.U. z 1997 r. Nr 121, poz. 769.

\section{ORZECZNICTWO}

Orzeczenie SN z dnia 10 maja 1935 roku, C II 354/35, Legalis nr 10816. Uchwała SN z dnia 24 lipca 2013 roku, III CZP 45/13, Legalis nr 703852. Wyrok NSA z dnia 27 października 2009 roku, II OSK 1690/08, Legalis nr 207850. Wyrok SA w Poznaniu z dnia 28 czerwca 1992 roku, I ACr 111/92, Legalis nr 877828. Wyrok SA w Szczecinie z dnia 31 lipca 2014 roku, III APa 4/14, Legalis nr 1231561. Wyrok SN z dnia 8 października 2004 roku, V CK 76/04, Legalis nr 68427. Wyrok SO w Szczecinie z dnia 4 lipca 2014 roku, VIII Gz 111/14, Legalis nr 1034103. Wyrok WSA w Warszawie z dnia 4 czerwca 2009 roku, VII Sa/Wa 486/09, Legalis nr 241252.

\section{DELIMITATION OF ACTIONS UNDERTAKEN BY AN INDEPENDENT PROXY}

\section{Summary}

The article presents the scope of an independent proxy authorization and reviews the provisions where a controversy arises in academic interpretation. The paper primarily focuses on the exemplification of the acts performed by the proxy by regrouping those acts into judicial, non-judicial and commercial ones. Finally, the author draws attention to a catalogue of the activities that can be undertaken by an independent proxy provided that he receives the special power of attorney. The catalogue placed in the Civil Code is not clear for both: the judiciary and the doctrine, thus it should be changed by the legislator. This study provides the readers with de lege ferenda solutions on the legislative vacuum of the independent proxy regulation.

Keywords: proxy, scope of authorization, (non-)judicial acts, running an undertaking, special power of attorney, restrictions of an independent proxy 